\title{
Birds of the Indigirka River Delta, Russia: Historical and Biogeographic Comparisons
}

\author{
JOHN M. PEARCE, ${ }^{1}$ DANIEL ESLER ${ }^{2}$ and ANDREI G. DEGTYAREV ${ }^{3}$
}

(Received 22 September 1997; accepted in revised form 4 May 1998)

\begin{abstract}
We documented the breeding status and relative abundance of all avian species on the coastal portion of the Indigirka River Delta during spring and summer 1993-95. Data on avifaunal composition were then compared to data from adjacent areas from Eastern Siberia to the Chukotka Peninsula to evaluate how species composition changes longitudinally within the arctic and typical tundra zones of northern Russia. We recorded 63 species on the Indigirka River Delta, 37 (58.7\%) of which were confirmed breeders during at least one of the three years. Five new species were recorded breeding (Arenaria interpres, Calidris acuminata, Limnodromus scolopaceus, Stercorarius parasiticus, and Asioflammeus), and 13 previously unrecorded species were observed during this study. We also identified several species of rare or threatened status in Russia and North America, including Branta bernicla, Somateria fischeri, Polysticta stelleri, and Rhodostethia rosea. We used parsimony and distance matrix methods to compare the breeding species richness on the Indigirka River Delta to that of six other Russian Arctic areas. Biogeographic comparisons revealed the presence of two clades in the Russian Arctic: the Lena River Delta east to Chaun Delta and the Chukotka Peninsula.
\end{abstract}

Key words: Arctic birds, Indigirka River, Russia, bird distribution, biogeography

РЕфЕРАТ: Материары по характеру прибывания и относительному обилию птид собраны весной и хетом 1993-1995 гГ. в Приморском поясе делты Индигирки. В этом районе установлено обитание 63 видов птиџ, из которых 37 (58.7\%) зарегистрированы в качестве гнездяцихся по крайнй мере раз в течение трех лет наблюдении. Отмечено 13 новых видов, а у 5 (Arenaria interpres, Calidris acuminata, Limnodromus scolopaceus, Stercorarius parasiticus, and Asio flammeus) установлен факт гнездования. В делте Индигирки обнаружены птиды, имеующие статус редких й исчесаующи в Северной Америке и России, в том числе Branta bernicla, Somateria fischeri, Polysticta stelleri, and Rhodostethia rosea. Для выяснения закономерностей изменений орнитофауны арктических и субарктических тундр в меридиональном направлений проведено сравнение видого состава и обилия гнездяџихся птиџ дехты Индигирки и шести территории, расположенных между делтой Лены и чукоткой. Дендрограммы показали наличие двух орнитогеографических регионов в восточном секторе россииской Арктики: один из них расположен между дехтами рек Лена и Чаун, другой - на Чукотском Полустрове.

Ключевые слова: арктические птиды, делта Индигирки, Россия, распостранение птид, биогеография

RÉSUMÉ. Durant le printemps et l'été de 1993-95, on a documenté le statut de reproducteurs ainsi que l'abondance relative de toutes les espèces aviaires dans la partie littorale du delta de l'Indigirka. On a ensuite comparé les données sur la composition aviaire à des données provenant de régions contiguës allant de la Sibérie orientale à la péninsule Tchoukotka, en vue d'évaluer la façon dont la composition des espèces évolue longitudinalement à l'intérieur des zones arctiques et des zones typiques de la toundra de la Russie septentrionale. On a enregistré 63 espèces dans le delta de l'Indigirka, dont 37 (58,7 p. cent) étaient des reproducteurs durant au moins une des trois années. On a enregistré cinq nouvelles espèces reproductrices (Arenaria interpres, Calidris acuminata, Limnodromus scolopaceus, Stercocarius parasiticus et Asio flammeus), et, au cours de l'étude, on a observé 13 espèces qui n'avaient jamais été relevées auparavant. On a aussi identifié plusieurs espèces classées rares ou menacées en Russie et en Amérique du Nord, y compris Branta bernicla, Somateria fischeri, Polysticta stelleri et Rhodostethia rosea. On a employé les méthodes de parcimonie et de matrices de distance pour comparer la diversité des espèces reproductrices présentes dans le delta de l'Indigirka avec six autres régions arctiques de Russie. Les

\footnotetext{
${ }^{1}$ Alaska Science Center, U.S. Geological Survey, Biological Resources Division, 1011 E. Tudor Road, Anchorage, Alaska 99503, U.S.A.; john_pearce@nbs.gov

${ }^{2}$ Alaska Science Center, U.S. Geological Survey, Biological Resources Division, 1011 E. Tudor Road, Anchorage, Alaska 99503, U.S.A.

${ }^{3}$ Yakutsk Institute of Biology, Laboratory of Ornithology, 41 Prospekt Lenina, Yaktusk 677891, Russia; present address: Department of Biological Resources, 14 Ul. Sverdlova, Yakutsk 677005, Russia

(C) The Arctic Institute of North America
} 
comparaisons biogéographiques ont révélé la présence de deux clades dans l'Arctique russe: le delta de la Lena à l'est jusqu'au delta du fleuve Chaun, et la péninsule Tchoukotka.

Mots clés: oiseaux arctiques, Indigirka, Russie, distribution aviaire, biogéographie

Traduit pour la revue Arctic par Nésida Loyer.

\section{INTRODUCTION}

Studies of geographical distribution of breeding birds in the Russian Arctic use a system of stratified arctic tundra habitats, grouped into latitudinal zones, to characterize affiliated avian species (Treshnikov, 1985; Kistchinskii, 1988; Stishov et al., 1989). Across Siberia and the Russian Far East, these zones, moving from lower to higher latitude, include the southern tundra (forest, taiga, and shrub tundras), the typical tundra (or moss-lichen tundra), the arctic tundra (composed of southern, central, and northern subzones), and the arctic desert (Treshnikov, 1985; Kistchinskii, 1988). Previous studies have found that (1) each zone contains characteristic and polyzonal species; (2) species richness declines with increasing latitude, and (3) that more holarctic species breed in northerly than southerly zones (Kistchinskii, 1988; Stishov et al., 1989). Documentation of avian assemblages within these zones provides a better understanding of the evolution of foraging ecology and overall life history strategies of associated species.

Latitudinal distribution of birds has been studied extensively on the Indigirka River, located on the northern coast of the Republic of Sakha (Yakutia). Pleske (1928) summarized ornithological data collected during expeditions by Zhitkov, Birula, and Buturlin and Roznowski. Mikhel (1935) compiled the first comprehensive annotated list for the Indigirka River basin and interior (>30 km inland) delta. He concluded that the Indigirka River Delta was not unique ornithologically, but contained palearctic and holarctic species. Uspenskii et al. (1962a, b) compiled an annotated bird list for the area north of $70^{\circ} \mathrm{N}$ latitude, focusing to a greater extent on the coastal portion of the Indigirka River Delta (IRD) and Khromskaya Bay (Fig. 1). They found that the IRD was an important nesting and moulting area for waterfowl and noted that species richness was more depauperate than in areas farther east near the Bering Sea. Zasypkin (1981) tested Uspenskii et al.'s (1962b) hypothesis of longitudinal variation in species distribution by comparing avian breeding records within different regions of the Russian arctic tundra province (from the Yana River Delta east to the Chukotka Peninsula) and computing pairwise similarity coefficients. He concluded that avifaunal characteristics of the Bering Sea were found only within the Chukotka Peninsula region, while areas from the Chaun River west to the Yana River Delta constituted one Eastern Siberian region. He therefore suggested that a boundary dividing these two unique avifaunal regions be placed at Point Shelagskii, just east of the Chaun Delta (Fig. 1).
Our first objective in this study was to provide a revised annotated list of all species within the coastal portion of the IRD and to note their general abundance. Second, we assessed changes in the presence of breeding species by comparing our records to the historical account of Uspenskii et al. (1962a, b). Third, we examined the avifaunal composition of the IRD in comparison to that of adjacent coastal Arctic areas within Eastern Siberia to investigate unique and shared attributes of the IRD avifauna. Finally, we compared records for these areas to breeding records from the Chukotka Peninsula to examine the west-east gradient suggested by Uspenskii et al. (1962b) and the regional groupings proposed by Zasypkin (1981).

\section{STUDY AREA AND METHODOLOGY}

The IRD $\left(71^{\circ} 20^{\prime} \mathrm{N}, 150^{\circ} 20^{\prime} \mathrm{E}\right)$ is one of four major Arctic river deltas in the Republic of Sakha (Yakutia) of Eastern Siberia (Fig. 1). Located at the western edge of Beringia (West, 1996), the IRD consists of approximately $5000 \mathrm{~km}^{2}$ in the southern subzone of the arctic tundra biome (Treshnikov, 1985; Stishov et al., 1989). This biome occurs from the Lena River Delta to the eastern edge of the Chukotka Peninsula. Vegetation, characteristic of arctic polygonal tundra, includes Carex stans, Eriophorum spp., Arctophila fulva, Poa spp., dwarf Salix spp., and Sphagnum spp. (Uspenskii et al., 1962a; Matveev, 1989). Pockets of typical tundra are found on the interior portion of the IRD and occur over most of the Kolyma and Chaun River Deltas and eastern Chukotka (see map in Kistchinskii, 1988:18).

We recorded the presence and activity of all species on two study sites within the coastal zone $(10-15 \mathrm{~km}$ inland from the sea coast) of the IRD (Fig. 1) from 9 to 25 June 1993, from 1 June to 24 July 1994, and from 6 June to 24 July 1995 . The interior site, located $25 \mathrm{~km}$ inland from the coast near Tabor, consisted of approximately $12 \mathrm{~km}^{2}$ of polygonal tundra and several large drained-basin complexes (Bergman et al., 1977). Basin complexes were characterized by deep $(>1 \mathrm{~m})$ lakes and ponds, often containing numerous small islands $\left(<9 \mathrm{~m}^{2}\right)$. Polygon ridges and pingos often rose several metres above surrounding wet tundra, creating more xeric vegetative communities. The coastal study area (approximately $25 \mathrm{~km}^{2}$ ), situated at the mouth of the central river channel, included ten islands, averaging $160 \mathrm{~m}^{2}$ in size, that were part of a larger coastal island archipelago. The few water bodies present on these coastal islands were deep lakes and ponds with emergent Arctophyla fulva. Island vegetation consisted primarily of wet Eriophorum spp. meadows and areas of 


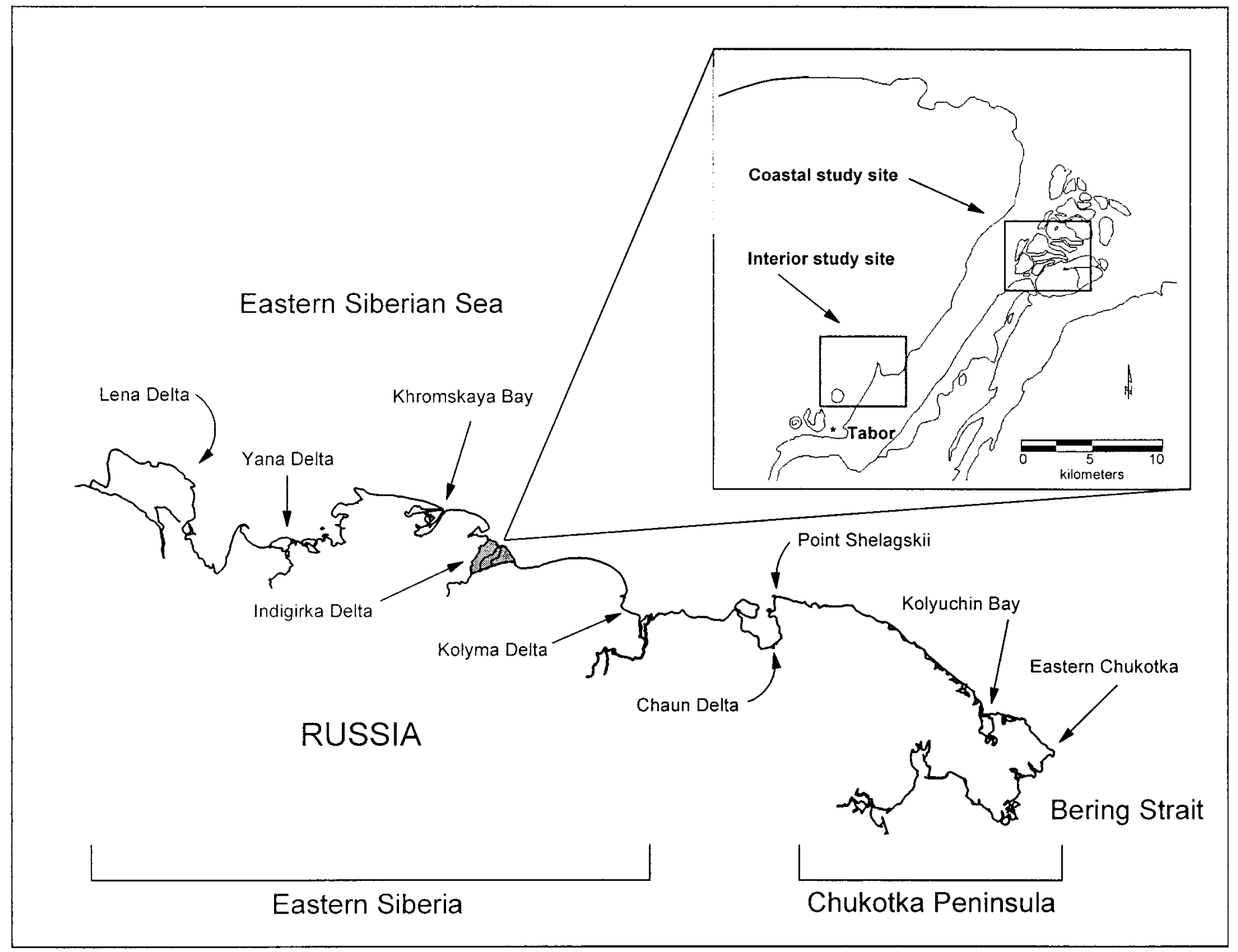

FIG. 1. Location of the Indigirka River Delta and other major riverine areas in the Russian Arctic. The area defined as the Indigirka River Delta proper is shaded, and coastal and interior study sites are shown on the inset.

dry grasses and dwarf willows. Interior tundra and wetlands were typically free of snow and ice by mid-June, and river channels broke by 20 June. Summer temperatures ranged from $-4^{\circ}$ to $22^{\circ} \mathrm{C}$, with an average of $5^{\circ} \mathrm{C}$. We believe the combination of these two study sites is representative of coastal IRD arctic tundra habitat.

The relative abundance and breeding status of each species were calculated by averaging daily observations at both study sites across the breeding season (ca. 15 June 25 July) using general abundance categories from Forbes et al. (1992). Categories were defined as follows: abundant (> 30 individuals per day), common (20-29), uncommon (4-19), occasional (2-3), and rare (1). Breeding status was defined as follows: breeder (nests or young birds observed); presumed breeder (breeding behaviour, such as territorial displays, observed for a species within its expected breeding range); migrant (birds observed moving in a directional manner, often in flocks, during spring or late summer); and transient (irregular visitor outside its known or suspected breeding area).
To examine temporal changes in the presence of breeding species on the coastal zone of the IRD, we limited our analyses to species recorded by Uspenskii et al. (1962a, b) within the arctic and typical tundra zones of the coastal IRD. For comparisons to other Russian Arctic areas, we added breeding records obtained by Mikhel (1935) and Uspenskii et al. (1962a, b) from further interior sites, but still within the IRD proper (defined as north of $71^{\circ} 50^{\prime} \mathrm{N}$ and east of $149^{\circ} \mathrm{E}$; see Fig. 1), an area that contains both arctic and typical tundra habitat zones. We then surveyed the literature for breeding records from adjacent Arctic areas of Eastern Siberia and the Chukotka Peninsula. In our review of published accounts, our objective was to compare only among lowland tundra habitats. Therefore, we excluded observations made south of the arctic and typical tundra zones, those made within higher altitude alpine tundra areas, and those made in seabird colonies. As our intent was to first summarize the complete avifauna of the IRD and then examine its relationship to other areas in terms of breeding species, we also excluded records of 
TABLE 1. Numbers of breeding species noted in coastal arctic areas, grouped by taxonomic order.

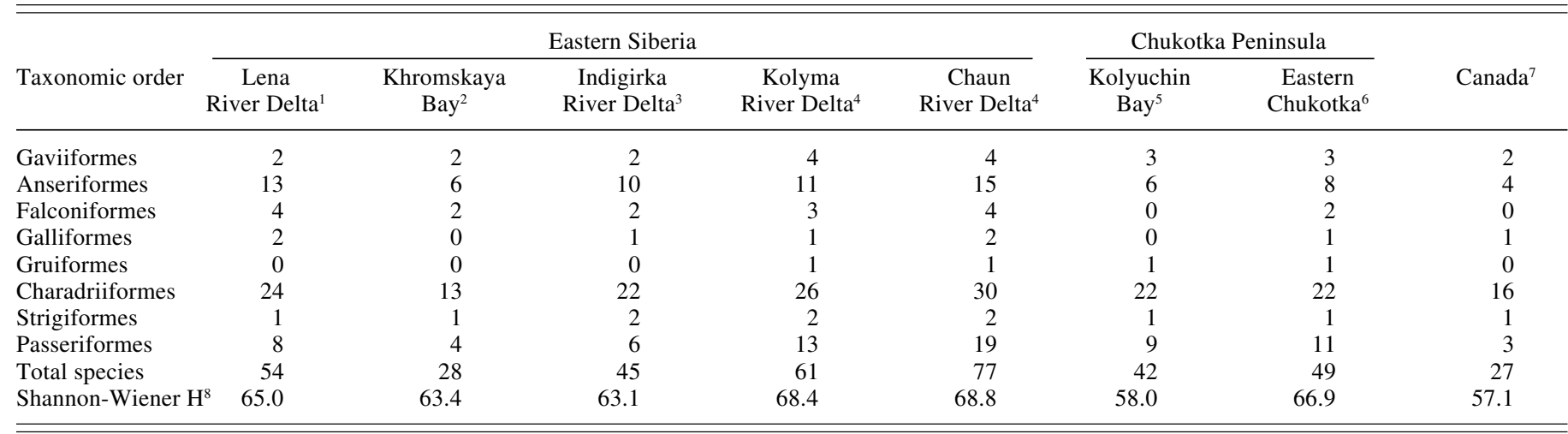

${ }^{1}$ Labutin et al., 1985; Blokhin, 1991.

${ }^{2}$ Uspenskii et al., 1962a, b.

${ }^{3}$ This study (plus those in Appendix 1, Note 4).

${ }^{4}$ Krechmar et al., 1991.

${ }^{5}$ Krechmar et al., 1978.

${ }^{6}$ Tomkovich and Sorokin, 1983 (southern study area observations near Provideniya are not included).

${ }^{7}$ Forbes et al., 1992.

${ }^{8}$ Taxonomic order diversity index (see Methods).

migrants or transients from other areas if no sight record existed for the IRD. Species records from each area were summarized by taxonomic order, and the proportion of breeding species within each group (number of species in a taxonomic group/total number of species for the area) was used to compute the Shannon-Weiner function (Krebs, 1989), a simple index of taxonomic diversity.

To examine which areas shared the most individual species, we performed a parsimony analysis using PAUP, version 3.1 (Swofford, 1993), using the breeding status of each species as a binary variable $(1=$ breeding; $0=$ not breeding). Presumed or possible breeding records and all invariant species (i.e., those breeding or not breeding at all sites) were excluded from analyses. Parsimony analysis strives for the simplest solution (involving the fewest steps) regarding the interrelationship of compared units by starting with a common ancestor and moving to more "evolved" taxa (see Swofford et al., 1996). In this case, geographic areas with fewer breeding species will be "ancestral" to more species-rich areas. To evaluate the most optimal relationship of areas included in the analysis, we bootstrapped (resampled with replacement) the data set 500 times and then examined all possible area relationships using the branch-and-bound method (Swofford et al., 1996). The species list of Forbes et al. (1992) was included as an outgroup, as it is located within the arctic tundra zone, but not on the Asian continent. Goodness-offit of parsimony trees was evaluated by computing a consensus tree and examining bootstrap values: the proportion of the pseudoreplicated data set that demonstrated a particular relationship between compared areas. To complement the parsimony analysis, we also calculated pairwise squared Euclidian distances between all areas to examine their similarity with regard to the presence and absence of breeding species. The distance matrix was then used in an unweighted pair-group method using arithmetic averages (UPGMA) cluster analysis in SPSS (1993).

\section{RESULTS}

We recorded a total of 63 species on the coastal IRD during the 1993-95 study period (Appendix 1). Thirtyseven species $(58.7 \%)$ were confirmed breeders in one of the three years. The majority of breeding species were waders (Table 1). Four species (Limnosa lapponica, Gallinago gallinago, G. stenura, and Stercorarius pomarinus) were defined as probable breeders because they displayed nesting behaviour throughout the breeding season, but no nests or young were discovered. Twenty $(31.7 \%)$ species were classified as transients. Breeding species were more numerous on the interior study site $(\mathrm{n}=$ $34)$ than on the coastal site $(n=16)$ and were primarily of the order Charadriiformes $(n=18)$. Nesting Passeriformes were found almost exclusively on the interior site. Coastal site breeders were more evenly represented by Anseriformes $(n=6)$ and Charadriiformes $(n=8)$. We found several species to be common or abundant migrants during the early spring (c. 5-15 June; Appendix 1). Limosa lapponica was the only summer (c. 25 June-15 July) migrant, as flocks, often as large as 30 birds, were observed moving northwest over both study sites daily.

We compared our 63 species records with the annotated lists of Mikhel (1935) and Uspenskii et al. (1962a, b). We documented five new breeding records (Arenaria interpres, Calidris acuminata, Limnodromus scolopaceus, Stercorarius parasiticus, and Asio flammeus) and observed 13 previously unrecorded species (Anas crecca, 

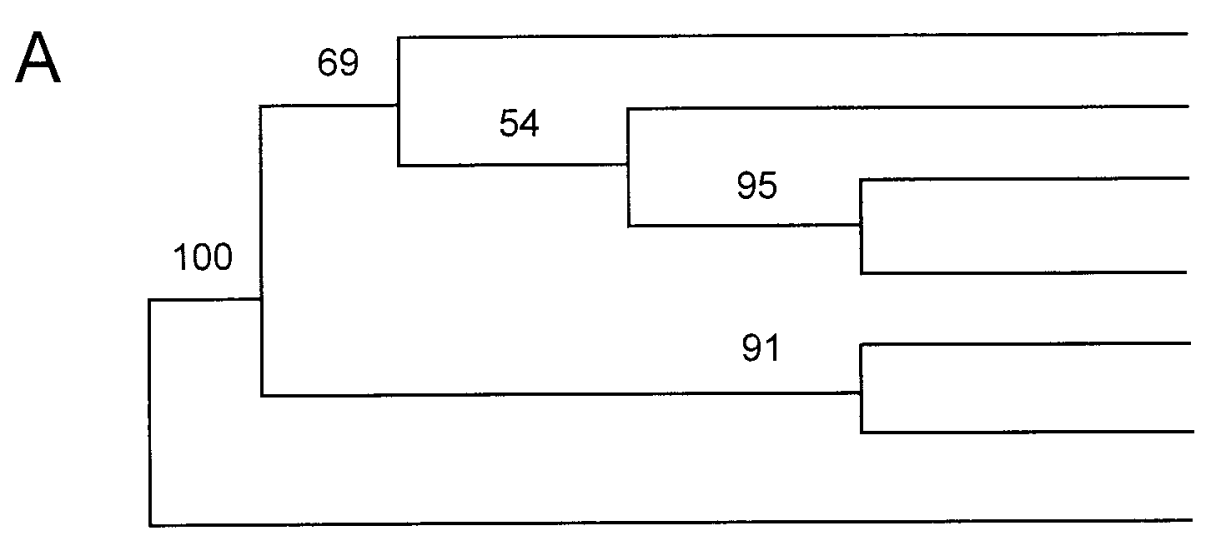

Indigirka Delta

Lena Delta

Kolyma Delta

Chaun Delta

Kolyuchin Bay

E. Chukotka

Outgroup (Canada)
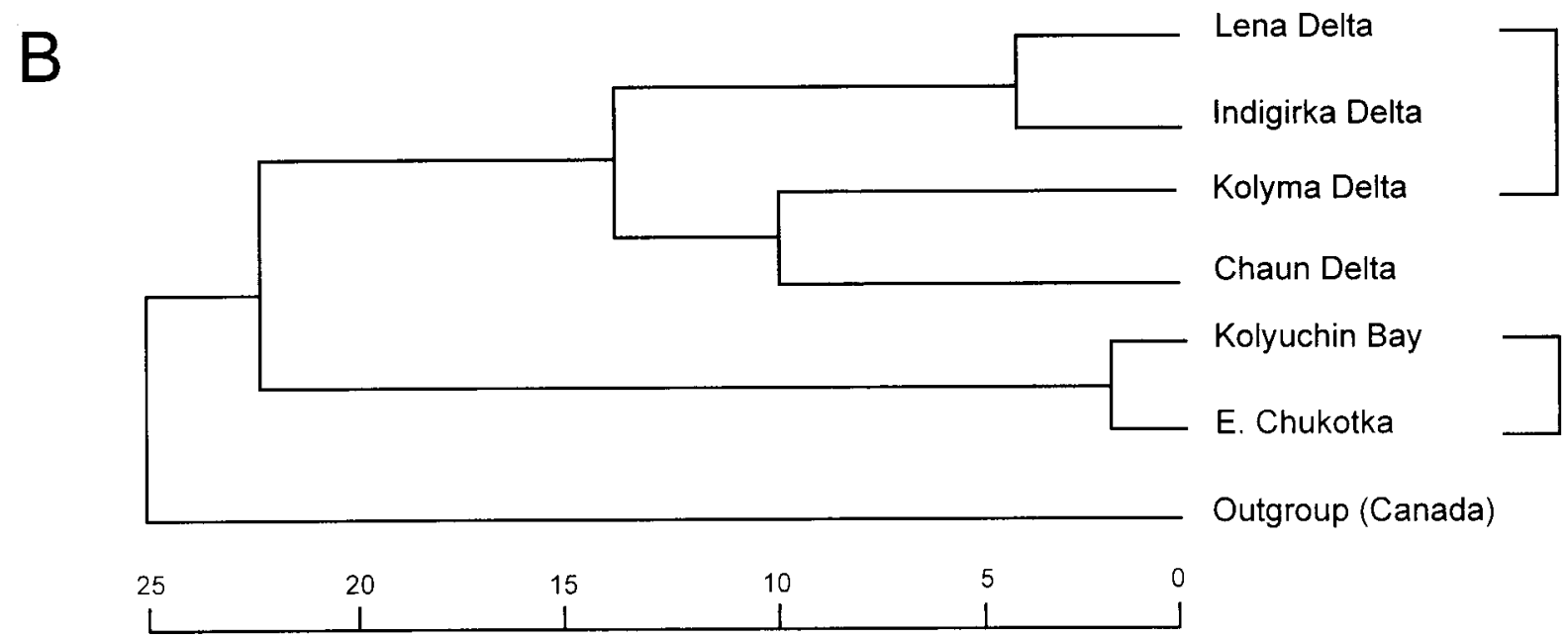

FIG. 2. A bootstrapped 50\% majority-rule consensus dendrogram (A) and a UPGMA dendrogram (B) of Russian Arctic areas in relation to presence and absence of breeding species. A rescaled distance coefficient legend is shown for the UPGMA dendrogram. Analyses included all areas except Khromskaya Bay (see Results and Discussion).

A. clypeata, A. penelope, Melanittafusca, Grus canadensis, Tringa glareola, Calidris canutus, Gallinago stenura, Hirundo rustica, Corvus corax, Turdus naumanni, Lanius cristatus, and Emberiza pusilla) for the IRD proper (Fig. 1). These species either were not mentioned in the accounts of Mikhel (1935) or Uspenskii et al. (1962a, b), or had been sighted by one or both of these authors well south of the IRD. We found no evidence of breeding for Anser fabalis, Chen caerulescens, Pluvialis fulva, Charadrius morinellus, Gallinago gallinago, Stercorarius pomarinus, Xema sabinii, and Oeanthe oeanthe, species which Uspenski et al. (1962a, b) had previously noted as breeding on the IRD (see Appendix 1). We also did not observe Anser erythropus. Falco peregrinus was the only species noted as breeding by Mikhel (1935) on the interior IRD that was not observed nesting by Uspenskii et al. (1962a, b) or during this study.

A comparison among five of the Arctic river deltas west of the Chukotka Peninsula indicated that the IRD and Khromskaya Bay were the most depauperate in terms of overall species diversity and number of species within certain taxonomic orders (Table 1). The IRD was especially lacking species in the orders Anseriformes and Passeriformes, while Khromskaya Bay had few species in the order Charadriiformes. The Kolyma and Chaun Deltas had the largest numbers of Passeriformes of all the areas examined.

Thirteen species were excluded from Appendix 1 before the cladistic analysis because they were either breeding at all eight locations or nonbreeding. The bootstrapped $50 \%$ consensus parsimony tree maintained the same tree topology regardless of the branch-and-bound method used. The tree grouped all areas, with the exception of Khromskaya Bay and the outgroup, into one large and poorly resolved clade (not shown). Further investigation of breeding records from Khromskaya Bay prompted us to exclude the area as an outlier (see Discussion for justification). The resulting tree (Fig. 2A) consisted of Eastern Siberia and Chukotka clades. Areas on the Chukotka Peninsula and the Kolyma and Chaun River Deltas were consistently grouped, but in separate clades, because of unique breeding species within these areas, but not shared across the regions of Eastern Siberia and Chukotka. The IRD did not group closely with any of the other sites, while 
the Lena River, Kolyma, and Chaun Deltas grouped together in only $54 \%$ of bootstrap iterations. The UPGMA cluster dendrogram, after excluding Khromskaya Bay, gave a nearly identical topology (Fig. 2B) to the parsimony tree; the only difference was that the IRD and Lena Delta were grouped together within the Eastern Siberia cluster. The rescaled distance coefficients (Fig. 2B) suggest that the Kolyma and Chaun Deltas are less similar to each other than are the IRD and the Lena Delta. Kolyuchin Bay and Eastern Chukotka demonstrate a very small distance coefficient, reflecting their nearly identical breeding species composition (Appendix 1). The Eastern Siberia and Chukotka Peninsula areas appear to be different in terms of species composition, given the bootstrap values from the parsimony analysis (91\%, Fig. 2A) and the large distance coefficient between these two clades (Fig. 2B).

\section{DISCUSSION}

\section{Contemporary and Historical Avifauna on the IRD}

We observed more breeding species on the interior study site of the IRD, presumably because of the greater diversity in landscape and wetland types observed there. Interior areas experience earlier snowmelt and different temperature regimes that most likely create greater vegetative diversity and therefore permit use by species with different habitat requirements. During three seasons on the coastal IRD, we documented five new breeding records and noted 13 previously unrecorded species. Most surprising was our discovery of Arenaria interpres, which had not been observed breeding by Mikhel (1935) or Uspenskii et al. (1962a, b), but was found nesting every year during our study on both interior and coastal sites. The remaining new breeding records were all single nests found in one or more years and represent rare breeding species that may be difficult to detect. For example, Motacilla alba was found nesting on both study sites only in relation to human dwellings, and Calidris acuminata appeared to nest only within a small portion of the interior site. Also, species such as Asioflammeus may not breed every year as a result of lemming abundance cycles. We may have failed to detect breeding Pluvialis fulva, Charadrius morinellus, Gallinago gallinago, G. stenura, Stercorarius pomarinus, Xema sabinii, and Oeanthe oeanthe for similar reasons. We do not believe that the population status of these species is changing. Rather, they are only found breeding in certain habitats or in the presence of certain annually variable circumstances and, as a result, may not be observed in every year.

The disappearance of historically abundant populations of Anser fabalis and A. albifrons noted by Mikhel (1935) and Uspenskii et al. (1962a, b) is corroborated by this study, as very few birds of these species were seen after spring migration, and nesting was rare (only one nest of A. albifrons was found during this study). Also, Chen caerulescens was not observed, even though aerial surveys of the entire IRD were conducted in 1993-95 (Pearce and Esler, unpubl. data; Hodges and Eldridge, 1995, 1996). Excessive local harvest of moulting geese on the IRD during the late 1800 s and early 1900 s has been suggested as the most likely reason for the decline of these species (Uspenskii et al., 1962b; Beme et al., 1965; Perfilev, 1987), although hunting pressure on Asian wintering areas may also have contributed to population declines of Anser spp. (Kistchinskii, 1973, 1988).

Several of the new IRD sight records were most likely due to spring storms that may have temporarily altered the migratory pathways of these species, while others may represent legitimate spring migrants moving to nesting grounds. For example, Grus canadensis is thought to be extending its breeding range westward toward interior areas of the IRD and Khromskaya Bay (Labutin and Degtyarev, 1988), and Calidris canutus breeds on coastal arctic tundra west of the IRD and on the New Siberian Islands $\left(74^{\circ} \mathrm{N}, 140^{\circ} \mathrm{E}\right)$. Transients noted in July were primarily male waterfowl (e.g., Aythya marila, Anas clypeata, and Melanita fusca), possibly en route to fall staging and moulting areas.

The presence of several palearctic and holarctic species on the IRD led Mikhel (1935) to conclude that the IRD was not unique. However, the numerous species of breeding shorebirds (Table 1), the large number of breeding Somateria fischeri, listed as threatened in 1993 (Stehn et al., 1993; U.S. Fish and Wildlife Service, 1993), and the occurrence of four species (Cygnus columbianus, Branta bernicla, Polysticta stelleri, and Rhodostethia rosea), although only as rare breeders, that are listed in the Republic of Sakha (Yakutia) Red Book of endangered species (Solomonov, 1987), are evidence that the IRD is an important arctic wetland area.

\section{Biogeographic Comparisons}

Both parsimony and distance trees demonstrated that areas in Eastern Siberia and Chukotka differ in terms of species composition (Fig. 2). Areas on the Chukotka Peninsula harbor unique Beringian species that do not breed or are rare transients west of Chaun Bay (e.g., Chen canagica, Calidris mauri, and Eurynorhynchus pygmaeus; Appendix 1). Geographically speaking, Chaun Bay is not included within Siberia or Chukotka, but our analysis is in agreement with Zasypkin's (1981) finding that the Chaun and Kolyma Deltas possess breeding species unique to the Russian north coast, but also share species from across Eastern Siberia. As a result, the avifauna of these areas exhibit greater similarity to those of the Eastern Siberian subprovince than to those of Chukotka.

Within the Eastern Siberia region, the Lena River, Khromskaya Bay, and IRD are all located within the arctic tundra zone and have similar geographic and habitat characteristics (Treshnikov, 1985; Kistchinskii, 1988). However, the Lena River exhibits a greater number of 
species within some orders, such as Anseriformes, Falconiformes, and Charadriiformes. The larger number of Anseriformes appears to result from the greater number of European flyway species (e.g., Cygnus cygnus) and boreal species (e.g., Melanitta nigra and Mergus serrator) that occur because certain habitat features extend farther north along the Lena River toward the delta. Isolated cliff habitats for Falconiformes, which exist on the Lena River Delta (Labutin et al., 1985), most likely contribute to sightings and breeding records for these species. While five species breed solely on the Lena River Delta, there are no breeding species found only within the three Eastern Siberia areas or solely on the IRD. The lower species diversity on the IRD places it outside the Eastern Siberia clade in the parsimony analysis. Unique breeding species and a greater number of Anseriformes separate the Lena River Delta from the IRD (Fig. 2A). However, this branch is poorly supported (54\% of bootstrap iterations), most likely because of similarities in the number of other taxonomic orders shared between these two areas. This is also reflected by the shorter distance between these two areas in the UPGMA dendrogram (Fig. 2B).

The depauperate avifauna noted in the Khromskaya Bay region may be due in part to higher latitude, but could also be the result of insufficient sampling. Uspenskii et al. $(1962 a, b)$ studied the area from mid-May to the end of June in 1960, but did not record several species (e.g., Lagopus lagopus, Arenaria interpres, Sterna paradisaea, and Motacilla alba) that have recently been observed to breed there (R. Gill, Jr., pers. comm. 1997). When these species were experimentally included in the data set, Khromskaya Bay was no longer an outlier, but grouped within the Eastern Siberia clade. However, its relationship to other Eastern Siberia areas was poorly supported (50\% of iterations). Given this result and our initial analyses, which included Khromskaya Bay, we feel our dendrograms are more informative when Khromskaya Bay is excluded from the analyses.

The consistent clustering of the Kolyma and Chaun Deltas and the Chukotka areas is not surprising considering their proximity to more southern and alpine tundra zones and, for the Chukotka areas, the proximity of North American avifauna (Tomkovich and Sorokin, 1983). The influence of diverse habitat zones on species community structure may be particularly pronounced on the Kolyma River Delta, as the delta is only a small portion of the greater Kolyma River lowland, an unforested southerly extension of the delta that contains habitats typical of more southern tundra (Krechmar et al., 1991; A. Andreev, pers. comm. 1997). The Chaun Delta represents the extreme of what Uspenskii et al. (1962b) referred to as having an "eastern orientation," meaning that it possessed a greater species richness than areas farther west in the Siberian Arctic. While species shared with adjacent areas place the Chaun Delta within the Eastern Siberia clade, six species that occur in common only with the Kolyma River Delta result in the grouping of these two areas in both cladistic analyses. The 11 unique breeding species recorded on the Chaun Delta increase its distance from the Kolyma Delta relative to distance comparisons between the IRD and Lena Delta or Kolyuchin Bay and Eastern Chukotka (Fig. 2B). Several of these species are palearctic, while others are truly unique to one or both of these areas (e.g., Limcola falcinellus and Calidris ruficolis), and some are more characteristic of the Beringian province suggested by Zasypkin (1981; e.g., Gavia adamsi, Somateria mollissima, and Grus canadensis). Tomkovich (1986) also showed the tendency for an increased species diversity nearer to the Bering Sea in regard to Calidrid waders. He hypothesized that this pattern was a result of low ice cover in Beringia during the last Ice Age, which resulted in the creation and preservation of certain breeding range limits for some species (see also Tomkovich and Sorokin, 1983).

\section{ACKNOWLEDGEMENTS}

We thank J. Hupp, D. Boyd, J. Lamoreux, E. Hopps, S. Sleptsov, and S. Troev for their observations and assistance during the study. Logistical support was graciously provided by I. Groshkov and V. Raevskii of the Indigirskaya Polar Station at Tabor. Additional logistical and financial support came from the Alaska Biological Science Center, the U.S. Fish and Wildlife Service Migratory Bird Management Office and Office of International Affairs, the National Oceanographic and Atmospheric Administration, the Yakutsk Institute of Biology, the Alaikhov Ecological Committee, and the Northern Forum. We especially appreciate the helpful editorial comments of P. Flint. Additional comments were made by D. Troy, R. Gill Jr., P. Tomkovich, C. Dau, D. Derksen, R. Lanctot, and one anonymous reviewer. S. and S. Talbot and B. Pierson are thanked for discussions regarding biogeographic comparisons. N. Tileston of the Alaska Resources Library and Information Services is thanked for assistance with reference materials.

\section{REFERENCES}

BEME, R.L., PRIKLONSKII, S.G., and USPENSKII, S.M. 1965. Vodoplavayushie delty Indigiki i ratsionalizatsiya ikh ispolzovaniya. [Waterfowl of the Indigirka River Delta and the rationalization of their use]. Ornitologiya 7:20-28.

BERGMAN, R.D., HOWARD, R.L., ABRAHAM, K.F., and WELLER, M.W. 1977. Water birds and their wetland resources in relation to oil development at Stokersen Point, Alaska. U.S. Fish and Wildlife Resource Publication 129. Washington, D.C.: U.S. Fish and Wildlife Service. 38 p.

BLOKHIN, Y.Y. 1991. O severnykh predelakh gnezdovaniya ptits o nizovyakh Leny. [On the northern breeding limits of some birds on the lower Lena River]. Ornitologiya 25:149150.

FORBES, G., ROBERTSON, K., OGILVIE, C., and SEDDON, L. 1992. Breeding densities, biogeography, and nest depredation of birds on Igloolik Island, N.W.T. Arctic 45:295-303. 
GUTHRIE, R.D. 1990. Frozen fauna of the mammoth steppe. Chicago: University of Chicago Press.

HODGES, J.I., and ELDRIDGE, W.D. 1995. Aerial waterfowl surveys on the arctic coast of eastern Russia, 1994. Unpubl. U.S. Fish and Wildlife Service Report. Available from Migratory Bird Management Office, U.S. Fish and Wildlife Service, 1011 E. Tudor Rd., Anchorage, Alaska 99503.

. 1996. Aerial waterfowl surveys near the arctic coast of Eastern Russia, 1995. Unpubl. U.S. Fish and Wildlife Service Report. Available from Migratory Bird Management Office, U.S. Fish and Wildlife Service, 1011 E. Tudor Rd., Anchorage, Alaska 99503.

KISTCHINSKII, A.A. 1973. Waterfowl of north-east Asia. Wildfowl 24:88-102.

- 1988. Ornitofauna severo-vostoka asii: Istoriya $\mathrm{i}$ sovremennoye sostoyanie. [Avifauna of northeastern Asia: History and modern state]. Moscow: Nauka.

KREBS, C.J. 1989. Ecological methodology. New York: Harper Collins.

KRECHMAR, A.V., ANDREEV, A.V., and KONDRATYEV, A.Y. 1978. Ecologiya i rasprostranenie ptits na severo-vostoke SSSR. [Ecology and distribution of birds in the northeastern USSR]. Moscow: Nauka.

- 1991. Ptitsi severnikh ravnin. [Birds of the northern plains]. Leningrad: Nauka. 288 p.

LABUTIN, Y.V., and DEGTYAREV, A.G. 1988. Kanadskii zhuravl

- Grus canadensis (Linnaeus) u zapadnoi granitsy ariala: razmeshchenie i chislennost. [The sandhill crane - Grus canadensis (Linnaeus) at the western edge of its range: Distribution and number]. In: Litvinenko, N.M., and Neifeldt, I.A., eds. Zhuravli palearktiki (Biologiya, morfologiya, rastprostranenie). Sbornik nauchnykh trudov. Vladivostok: Akademia Nauk SSSR. 161-164.

LABUTIN, Y.V., PERFILEVA, V.I., REVIN, Y.V., BLOKHIN, Y.Y., DEGTYAREV, A.G., DESYATKIN, R.V., EGOROVA, A.A., KIRILLOV, F.N., PERFILEV, V.I., and PETROVA, E.I. 1985. Rastitelnyi i zhivotnyi mir delty reki leny. [Flora and fauna of the Lena River Delta]. Yakutsk: Yakutskskii Filial Akademiya Nauk SSSR.

MATVEEV, I.A. 1989. Atlas selskogo khozyaistva Yakutskoi ASSR. [Agricultural atlas of the Yakut ASSR]. Moskow: Glavnoe upravlenie geodezii i kartographii pri sovete ministerstvo SSSR.

MIKHEL, N.M. 1935. Materiali po ptitsam Indigirskogo kraya [Information on the birds of the Indigirka Region]. Trudi Arkticheskogo Instituta 31.

PERFILEV, V.I. 1987. Piskulka [Status of the lesser white-fronted goose]. In: Solomonov, N.G., ed. Krasnaya kniga Yakustkoi ASSR. Novosibirsk: Nauka. 41-42.
PLESKE, T. 1928. Birds of the Eurasian tundra. Memoirs of the Boston Society of Natural History 6.

SOLOMONOV, N.G. 1987. Krasnaya kniga Yakustkoi ASSR [Red Book of the Yakutian ASSR]. Novosibirsk: Nauka.

SPSS (STATISTICAL PACKAGE FOR THE SOCIAL SCIENCES). 1993. Base system user's guide: Professional statistics, v. 6.0. Chicago, Illinois.

STEHN, R.A., DAU, C.P., CONANT, B., and BUTLER, W.I. 1993. Decline of spectacled eiders nesting in western Alaska. Arctic 46:264-277.

STISHOV, M.S., CHERNOV, Y.I., and VRONSKII, N.V. 1989. Fauna i nacelenie ptits podzony arkicheskikh tundr. [The bird fauna and population of arctic tundra subzones]. In: Chernov, Y.I., ed. Ptitsi v soobshestvakh tundrovoi zony. Moskow: Nauka. 5-39.

SWOFFORD, D.L. 1993. PAUP: Phylogenetic Analysis Using Parsimony, v. 3.1. Software formerly distributed by Illinois Natural History Survey, Champaign, Illinois.

SWOFFORD, D.L., OLSEN, G.J., WADDELL, P.J., and HILLIS, D.M. 1996. Phylogenetic inference. In: Hillis, D.M., Moritz, C., and Mable, B.K., eds. Molecular systematics. 2nd ed. Sunderland, Massachusetts: Sinauer Associates Inc. 407-512.

TOMKOVICH, P.S. 1986. Geographic breeding distribution of Calidris sandpipers in the Palearctic. Wader Study Group Bulletin $51: 25$.

TOMKOVICH, P.S., and SOROKIN, A.G. 1983. Fauna ptits vostochnoi chukotki. [Bird fauna of Eastern Chukotka]. In: Rossolimo, O.L., ed. Archives of the Zoological Museum, Moscow State University, v. 21. Moscow University Press. $77-$ 159.

TRESHNIKOV, D.F. 1985. Atlas Arktiki [Atlas of the Arctic]. Moskow: Glavnoe upravlenie geodezii i kartographii pri sovete ministerstvo SSSR.

U.S. FISH AND WILDLIFE SERVICE. 1993. Endangered and threatened wildlife and plants: Final rule to list spectacled eiders as threatened. Federal Register 58:27474-27480.

USPENSKII, S.M., BEME, P.L., PRIKLONSKII, S.G., and VEKHOV, V.H. 1962a. Ptitsi severo-vostoka yakutii. [Birds of northeastern Yakutia]. Ornitologia 4:64-86.

. 1962b. Ptitsi severo-vostoka yakutii. [Birds of northeastern Yakutia]. Ornitologia 5:49-67.

WEST, F.H. 1996. Preamble: The study of Beringia. In: West, F.H., ed. American beginnings. Chicago: University of Chicago Press.

ZASYPKIN, M.Y. 1981. Rasprostranenie ptits na zapadnoi Chukotke i zoogeograficheskii analiz ee avifauny. [The distribution of birds in western Chukotka and a zoogeographical analysis of its avifauna]. Ornitologiya 16:100-114. 
APPENDIX 1. Sight and breeding records of avian species for Indigirka River Delta study sites and other Russian Arctic areas ${ }^{1}$.

\begin{tabular}{|c|c|c|c|c|c|c|c|c|c|}
\hline \multirow{3}{*}{ Taxonomic order, species } & \multicolumn{6}{|c|}{ Eastern Siberia } & \multicolumn{2}{|c|}{ Chukotka Peninsula } & \multirow{3}{*}{ Canada $^{8}$} \\
\hline & \multirow[t]{2}{*}{ Lena $^{2}$} & \multirow[t]{2}{*}{ Khromskaya $^{3}$} & \multicolumn{2}{|c|}{ Indigirka $^{4}$} & \multirow[t]{2}{*}{ Kolyma $^{5}$} & \multirow[t]{2}{*}{ Chaun $^{5}$} & \multirow[t]{2}{*}{ Kolyuchin $^{6}$} & \multirow{2}{*}{$\begin{array}{c}\text { Eastern } \\
\text { Chukotka }^{7}\end{array}$} & \\
\hline & & & Interior & Coastal & & & & & \\
\hline GAVIIFORMES & & & & & & & & & \\
\hline Gavia stellata & B & B & Bo & + & B & B & B & B & B \\
\hline G. pacifica & - & - & ? & ? & B & B & B & B & B \\
\hline G. arctica & B & B & Bo & Bo & B & B & ? & + & - \\
\hline G. adamsi & + & - & - & - & B & B & B & B & - \\
\hline ANSERIFORMES & & & & & & & & & \\
\hline Cygnus columbianus & B & B & + & $\mathrm{Br}$ & $\mathrm{B}$ & B & + & B & - \\
\hline C. cygnus & B & - & - & - & + & - & - & - & - \\
\hline Anser fabalis & B & + & $\mathrm{M},+(\mathrm{B})$ & + & + & B & - & + & - \\
\hline A. erythropus & B & - & $?(+)$ & ? & + & + & - & - & - \\
\hline A. albifrons & B & B & $\mathrm{Br}$ & ? & B & B & B & + & - \\
\hline Chen caerulescens & - & - & $-(\mathrm{B})$ & - & + & + & + & + & $\mathrm{B}$ \\
\hline C. canagica & - & - & - & - & - & - & B & B & - \\
\hline Branta bernicla & B & + & $\mathrm{M},+$ & $\mathrm{Bc}$ & B & B & $\mathrm{B}$ ? & B & B \\
\hline Anas crecca & B & + & + & - & B & B & + & B & - \\
\hline A. formosa & + & + & + & - & + & + & + & - & - \\
\hline A. acuta & $\mathrm{B}$ & + & $\mathrm{Br}$ & + & B & B & B & B & - \\
\hline A. clypeata & + & - & $+(-)$ & - & + & + & + & + & - \\
\hline A. penelope & + & - & $+(-)$ & - & + & B & + & + & - \\
\hline A. marila & + & - & + & - & B & B & + & + & - \\
\hline Somateria mollissima & + & - & - & - & - & B & $\mathrm{B}$ & $\mathrm{B}$ & + \\
\hline S. spectabilis & B & B & $\mathrm{M},+$ & $\mathrm{Br}$ & B & B & + & + & B \\
\hline S. fischeri & + & B & $\mathrm{M}, \mathrm{Ba}$ & $\mathrm{Ba}$ & B & B & + & + & + \\
\hline Polysticta stelleri & $\mathrm{B}$ & B & $\mathrm{M}, \mathrm{Bu}$ & $\mathrm{Br}$ & B & + & + & + & - \\
\hline Clangula hyemalis & $\mathrm{B}$ & $\mathrm{B}$ & $\mathrm{M}, \mathrm{Br}$ & $\mathrm{Br}$ & $\mathrm{B}$ & $\mathrm{B}$ & $\mathrm{B}$ & $\mathrm{B}$ & B \\
\hline Melanitta nigra & B & - & - & - & + & B & - & - & - \\
\hline M. fusca & + & - & $+(-)$ & - & - & B & - & + & - \\
\hline Mergus serrator & B & - & $+(-)$ & - & B & B & B & B & - \\
\hline FALCONIFORMES & & & & & & & & & \\
\hline Buteo lagopus & $\mathrm{B}$ & B & $\mathrm{Br}$ & + & B & B & $\mathrm{B}$ ? & B & - \\
\hline Aquila chrysaetos & B & - & - & - & + & - & - & + & + \\
\hline Pandion haliaetus & - & - & - & - & - & B & - & - & - \\
\hline Falco peregrinus & B & B & $+(\mathrm{B})$ & + & B & B & + & B & + \\
\hline F. rusticolus & B & + & - & + & $\mathrm{B}$ & $\mathrm{B}$ & + & + & - \\
\hline GALLIFORMES & & & & & & & & & \\
\hline Lagopus lagopus & B & - & $\mathrm{Bu}$ & - & B & B & + & B & - \\
\hline L. mutus & B & + & - & - & + & $\mathrm{B}$ & - & + & $\mathrm{B}$ \\
\hline GRUIFORMES & & & & & & & & & \\
\hline Grus canadensis & - & - & $+(-)$ & - & $\mathrm{B}$ & B & B & B & + \\
\hline G. leucogeranus & + & - & + & - & + & + & - & - & - \\
\hline CHARADRIIFORMES & & & & & & & & & \\
\hline Pluvialis squatorola & B & B & $\mathrm{Bu}$ & + & $\mathrm{B}$ & B & $\mathrm{B}$ & $\mathrm{B}$ ? & $\mathrm{B}$ \\
\hline P. fulva & $\mathrm{B}$ & + & $-(\mathrm{B})$ & - & B & B & B & $\mathrm{B}$ & - \\
\hline P. dominica & - & - & - & - & - & - & - & + & B \\
\hline Charadrius hiaticula & B & - & - & - & + & B & B & B & - \\
\hline C. semipalmatus & - & - & - & - & - & - & - & - & B \\
\hline C. morinellus & B & B & - & - & + & B & $\mathrm{B}$ ? & B & - \\
\hline Tringa erythropus & + & - & $+(-)$ & + & B & B & - & - & - \\
\hline T. glareola & + & - & $+(-)$ & - & + & B & - & + & - \\
\hline Xenus cinereus & - & - & - & - & - & $\mathrm{B}$ & - & - & - \\
\hline Limnosa lapponica & B & - & $\mathrm{B} ?(-)$ & $\mathrm{M},+$ & $\mathrm{B}$ & $\mathrm{B}$ & + & + & - \\
\hline Arenaria interpres & B & + & $\mathrm{Br}(+)$ & $\mathrm{Br}$ & B & B & B & B & B \\
\hline Calidris tenuirostris & + & - & - & - & - & B & - & + & - \\
\hline C. canutus & - & - & $+(-)$ & + & - & + & - & + & + \\
\hline C. pusilla & - & - & - & - & - & - & - & + & $\mathrm{B}$ \\
\hline C. mauri & - & - & - & - & - & - & B & $\mathrm{B}$ & - \\
\hline C. ruficollis & + & - & - & - & B & B & B & B & - \\
\hline C. temminckii & B & B & $\mathrm{Bu}$ & $\mathrm{Br}$ & B & B & B & B & - \\
\hline C. minuta & B & B & $\mathrm{Br}$ & + & B & B & + & B & - \\
\hline C. fuscicollis & - & - & - & - & - & - & - & - & B \\
\hline C. bairdii & - & - & - & - & - & - & B & $\mathrm{B}$ & $\mathrm{B}$ \\
\hline C. melanotos & B & B & M, Bo & + & B & B & $\mathrm{B}$ & $\mathrm{B}$ & + \\
\hline C. acuminata & B & + & $\mathrm{Br}(-)$ & + & B & B & + & - & - \\
\hline C. maritima & - & - & - & - & - & - & - & - & $\mathrm{B}$ \\
\hline
\end{tabular}


APPENDIX 1.-cont. Sight and breeding records of avian species for Indigirka River Delta study sites and other Russian Arctic areas ${ }^{1}$.

\begin{tabular}{|c|c|c|c|c|c|c|c|c|c|}
\hline \multirow{3}{*}{ Taxonomic order, species } & \multicolumn{6}{|c|}{ Eastern Siberia } & \multicolumn{2}{|c|}{ Chukotka Peninsula } & \multirow{3}{*}{ Canada $^{8}$} \\
\hline & Lena $^{2}$ & Khromskaya $^{3}$ & & & Kolyma $^{5}$ & Chaun $^{5}$ & \multirow[t]{2}{*}{ Kolyuchin $^{6}$} & \multirow{2}{*}{$\begin{array}{c}\text { Eastern } \\
\text { Chukotka }^{7}\end{array}$} & \\
\hline & & & Interior & Coastal & & & & & \\
\hline
\end{tabular}

CHARADRIIFORMES - continued:

C. ptilocnemis

C. alpina

C. ferruginea

Eurynorhynchus pygmaeus -

Limicola falcinellus

Philomachus pugnax B

Limnodromus scolopaceus +

Lymnocryptes minimus +

Gallinago gallinago

G. stenura

Phalaropus lobatus

P. fulicaria

Stercorarius pomarinus

S. parasiticus

S. longicaudus

Larus argentatus

L. hyperboreus

L. thayeri

Rhodostethia rosea

Xema sabinii

Sterna paradisaea

-
B
B
-
-
B
+
+
B
+
B
B
B
B
B
B
B
-
B
B
B

B

-
B
B
-
-
-
-
-
+
-
B
B
B
+
B
B
B
-
+
-
+

$\begin{array}{ccc} & & \\ - & - & - \\ \mathrm{Bu} & + & \mathrm{B} \\ \mathrm{M}, \mathrm{Br} & - & \mathrm{B} \\ - & - & - \\ - & - & \mathrm{B} \\ \mathrm{Ba} & \mathrm{Bu} & \mathrm{B} \\ \mathrm{Br}(-) & - & \mathrm{B} \\ - & - & \mathrm{B} \\ \mathrm{B} ?(\mathrm{~B}) & \mathrm{B} ? & \mathrm{~B} \\ \mathrm{~B} ?(-) & - & + \\ \mathrm{Bu} & \mathrm{Bu} & \mathrm{B} \\ \mathrm{M}, \mathrm{Ba} & \mathrm{Bc} & \mathrm{B} \\ \mathrm{M},+ & \mathrm{B} ?(\mathrm{~B}) & \mathrm{B} \\ \mathrm{Br}(+) & \mathrm{Br} & \mathrm{B} \\ \mathrm{Br} & + & \mathrm{B} \\ \mathrm{M}, \mathrm{Bc} & \mathrm{Bu} & \mathrm{B} \\ \mathrm{Bu} & + & \mathrm{B} \\ - & - & - \\ \mathrm{M}, \mathrm{Bu} & \mathrm{Br} & \mathrm{B} \\ +(\mathrm{B}) & - & + \\ \mathrm{M}, \mathrm{Bo} & + & \mathrm{B} \\ & & \end{array}$

STRIGIFORMES
Nyctea scandiaca
Asio flammeus

B

$\begin{array}{cc}\text { B } & \mathrm{Br} \\ - & \mathrm{Br}(-)\end{array}$

Eremophila alpestris

Hirundo rustica

Riparia riparia

Delichon urbica

Corvus corvax

C. corone

Phylloscopus trochilus

P. collybitus

P. borealis

Luscinia svecica

Oenanthe oenanthe

Saxicola torquata

Catharus minimus

Turdus naumanni

Prunella montanella

Motacilla alba

M. flava

Anthus cervinus

A. gustavi

Lanius cristatus

Calcarius lapponicus

Emberiza pusilla

E. pallasi

Plectrophenax nivalis

Acanthis spp.

Leucosticte arctoa

\begin{tabular}{|c|c|c|c|}
\hline B & + & - & - \\
\hline- & - & - & $+(-)$ \\
\hline- & - & - & - \\
\hline+ & + & - & - \\
\hline+ & - & $+(-)$ & - \\
\hline+ & - & - & - \\
\hline- & - & - & - \\
\hline- & - & - & - \\
\hline- & - & - & - \\
\hline+ & - & - & - \\
\hline B & B & $+(\mathrm{B})$ & - \\
\hline- & - & - & - \\
\hline- & - & - & - \\
\hline- & - & $+(-)$ & - \\
\hline- & - & - & - \\
\hline B & + & $\mathrm{Br}(+)$ & $\mathrm{Br}$ \\
\hline+ & + & - & - \\
\hline B & B & $\mathrm{Br}$ & - \\
\hline- & - & - & - \\
\hline- & - & $+(-)$ & - \\
\hline B & B & Bo & - \\
\hline- & - & $+(-)$ & - \\
\hline- & - & - & - \\
\hline B & B & Bo & - \\
\hline B & + & $\mathrm{M}, \mathrm{Br}$ & - \\
\hline B & - & - & - \\
\hline
\end{tabular}

$\begin{array}{lllll}\text { B } & \text { B } & \text { B } & \text { B } & \text { B } \\ \text { B } & \text { B } & + & + & -\end{array}$

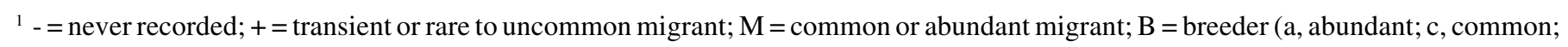
$\mathrm{u}$, uncommon; o, occasional; r, rare); B? = probable breeder; ? = uncertain species identification. Parentheses in the Indigirka column refer to contradictory records obtained by previous authors (see footnote 4 ).

${ }^{2}$ Labutin et al., 1985; Blokhin, 1991.

${ }^{3}$ Uspenskii et al., $1962 \mathrm{a}, \mathrm{b}$.

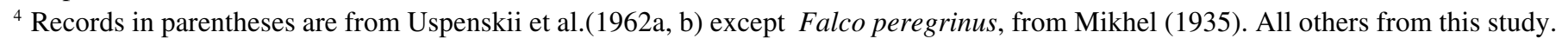

${ }^{5}$ Krechmar et al., 1991.

${ }^{6}$ Krechmar et al., 1978.

${ }^{7}$ Tomkovich and Sorokin, 1983 (southern study area observations near Provideniya are not included).

${ }^{8}$ Forbes et al., 1992. 